\title{
The Effect Of Oven Time On Physical Characteristics Of Cookies From Composite Flour (Rice Bran,Mocaf,Corn)
}

\author{
Syarifah Nur Asiyah ${ }^{1}$, Elsa Anugerah Pertiwi², Ratri Ariatmi Nugrahani ${ }^{3}$, \\ Nurul Hidayati Fithriyah ${ }^{4}$, Nelfiyanti ${ }^{5}$, Athiek Sri Redjeki ${ }^{6}$
}
1,2,3,4,6Department of Chemical Engineering, Faculty of Engineering, University of Muhammadiyah Jakarta, Jl Cempaka Putih Tengah No 27, Central Jakarta, DKI Jakarta 10510
${ }^{5}$ Department of Industrial Engineering, Faculty of Engineering, University of Muhammadiyah Jakarta, Jl Cempaka Putih Tengah No 27, Central Jakarta, DKI Jakarta 10510

Corresponding author's e-mail: syarifahnur.sn44@gmail.com

\begin{abstract}
Cookies are one of nutritious food preparations made from wheat flour. As the need for wheat flour increases, alternative flour substitutes for wheat flour are needed, for example composite flour such as rice bran,mocaf,corn. The use of composite flour in manufacture of cookies can improve nutritional value of product. This research aims to make cookies products with composite flour substitution, to know the physical characteristics of the spread factors, and to know the proximate levels. The research method is in two stages: the first stage is making of cookies with all-in method with variations in time of oven 10,13,15,17, 20 minutes on the physical analysis of spread factors. While the second stage is the proximate test (protein,fat,carbohydrate,moisture content,ash content) from the best oven time. The results showed that the spread factor was strongly influenced by the oven time. The best spread factor of 40.44 resulted in a more nutritious and healthier product at 20 minutes of oven time. Provide information on the utilization of composite flour (rice bran flour- mocaf flour- corn flour), Increase the nutritional content of cookies, Increase the added value of (rice bran, mocaf, and corn).
\end{abstract}

Keywords : cookies, spread factor, proximate content, composite flour

\section{Introduction}

Biscuits are foods that are classified as baked or dry food. Biscuits are made from basic ingredients of flour and other additives to form a formula, thus producing a product with a certain structure [1]. Biscuits are one of the main snacks consumed by the Indonesian population and are a nutritious processed food. Fulfilling the need for food and nutrition is an important factor in the development of quality Indonesian people in order to increase the nation's competitiveness [2].

Food raw materials include flour, currently the biggest need is wheat flour. Wheat flour is widely used by the food industry as a raw material in processing a food product. The greatest need for domestic flour comes from the small and medium-sized industrial groups (IKM) (Suryanto, 2008). Small and medium-sized industry is a type of business that has a market potential that is increasing every year so that it has an impact on increasing demand for wheat flour in Indonesia, it can be shown in BPS data In 2010, the consumption of wheat flour in Indonesia was 4.3 million tons, while in 2011 it increased to 4.6 million tons. 
Composite flour is a mixture of flour, starch, and other ingredients that aims to completely or partly replace the use of wheat flour in bread and pastry products or biscuits. Composite flour has the advantages of having a higher nutritional value compared to just one type of flour. and better physical quality [3].

Some of the composite flour for substituting or substituting wheat flour is mocaf flour. MOCAF (Modified Cassava Flour) is a modified cassava product. Several studies have shown the advantages of mocaf, namely the available raw materials are quite a lot and the price of cassava as a raw material is relatively cheap compared to the price of wheat as a raw material for wheat flour. The advantages of mocaf flour lie in physiological effects such as preventing colon cancer, having a hypoglycemic effect, but mocaf also has several drawbacks, namely that it has little protein content and does not contain gluten like wheat flour. Gluten free refers to gluten-free food products. Apart from mocaf, there are types of flour that come from industrial waste, for example rice bran, waste from rice mills [4].

Rice bran has a high protein nutrient content due to its high lysine content, lysine is an essential amino acid. [5] reported that the PER (protein efficiency ratio) value of rice bran is 1.6-1.9. According to [6], bran contains $14-16 \%$ protein, $12-23 \%$ fat, and $8-10 \%$ crude fiber.

Corn flour is relatively easy for the public to accept, because it is used to using flour, such as rice flour and wheat flour. The use of corn flour as a composite flour in various food ingredients, including for cakes, cookies, dry noodles, and breads. Composite corn flour can substitute $30-40 \%$ flour for wet cakes, $60-70 \%$ for pastries, and $10-15 \%$ for bread and noodles [7].

These ingredients can be processed into various types of food and cakes, such as cookies, bread and cakes. Although the taste of the processed product is not as good as using wheat flour, gluten free products are very good for health and are a food alternative for those who cannot consume gluten.

According to [8], there are two basic methods of mixing cookie dough, namely the cream method (creaming method) and the all-in method. In the cream method, all ingredients are not mixed directly, but are first mixed with fat and sugar, then milk is added, followed by the addition of aeration chemicals and salt that have previously been dissolved in water. While the method of making cookies is the all-in method, where all the ingredients are mixed directly.

This study aims to make cookies products with composite flour substitution, to determine the physical characteristics of the spread factors and the proximate levels of the best spread factors. It is hoped that this research can provide benefits in efforts to reduce the number of micronutrient deficiencies, especially in children.

\section{Research Method}

\subsection{Materials}

The raw materials needed are rice bran flour, mocaf flour, corn flour, wheat flour, refined sugar, eggs, margarine, powdered skim milk, salt, vanilla, cinnamon powder, baking powder. Rice bran from rice is obtained from rice mills.

The equipment used are calipers (PT. Indonesia Surya Sejahtera), mixers, ovens, scales.

Rice bran is first stabilized by heating at $120 \mathrm{oC}$ for 10 minutes to deactivate the lipase enzyme. Stable the rice bran is allowed to cool to room temperature and packed in an airtight container and stored

\subsection{Procedure}

The mixing of the ingredients for the cookies was carried out through a preliminary study referring to the research of Kusumawardani, et al., 2018, namely the composition of $25 \%$ composite flour with an oven temperature of $160^{\circ} \mathrm{C}$. Furthermore, in this study modified by the addition of 2.5 grams of cinnamon powder, 30 grams of powdered skim milk and removal of 
water. The method of mixing the dough uses the All in method.The dough is in the oven with oven time of 10,13,15,17, and 20 minutes then the spread factor is calculated.

Table 1. Ingredients for cookies

\begin{tabular}{|l|l|l|}
\hline \multirow{2}{*}{ material } & \multicolumn{2}{|l|}{ BMC Composite Flour } \\
\cline { 2 - 3 } & \multicolumn{2}{|l|}{ Mixed Food Ingredients) } \\
\hline & $\mathrm{I}$ & $\mathrm{II}$ \\
\hline Wheat Flour $(\mathrm{g})$ & 250 & 187.5 \\
\hline BMC flour $(\mathrm{g})$ & 0 & 62.5 \\
\hline Rice Bran Flour (g) & 0 & 20 \\
\hline Mocaf Flour (g) & 0 & 40 \\
\hline Corn Flour $(\mathrm{g})$ & 0 & 2.5 \\
\hline Butter $(\mathrm{g})$ & 150 & 150 \\
\hline Refined Sugar $(\mathrm{g})$ & 125 & 125 \\
\hline Egg Yolk (g) & 50 & 50 \\
\hline Skimmed Milk $(\mathrm{g})$ & 20 & 20 \\
\hline Baking powder $(\mathrm{g})$ & 2.5 & 2.5 \\
\hline Salt $(\mathrm{g})$ & 2.5 & 2.5 \\
\hline Vanilla (g) & 2.5 & 2.5 \\
\hline Cinnamon Powder $(\mathrm{g})$ & 2.5 & 2.5 \\
\hline
\end{tabular}

Fine granulated sugar, eggs, margarine

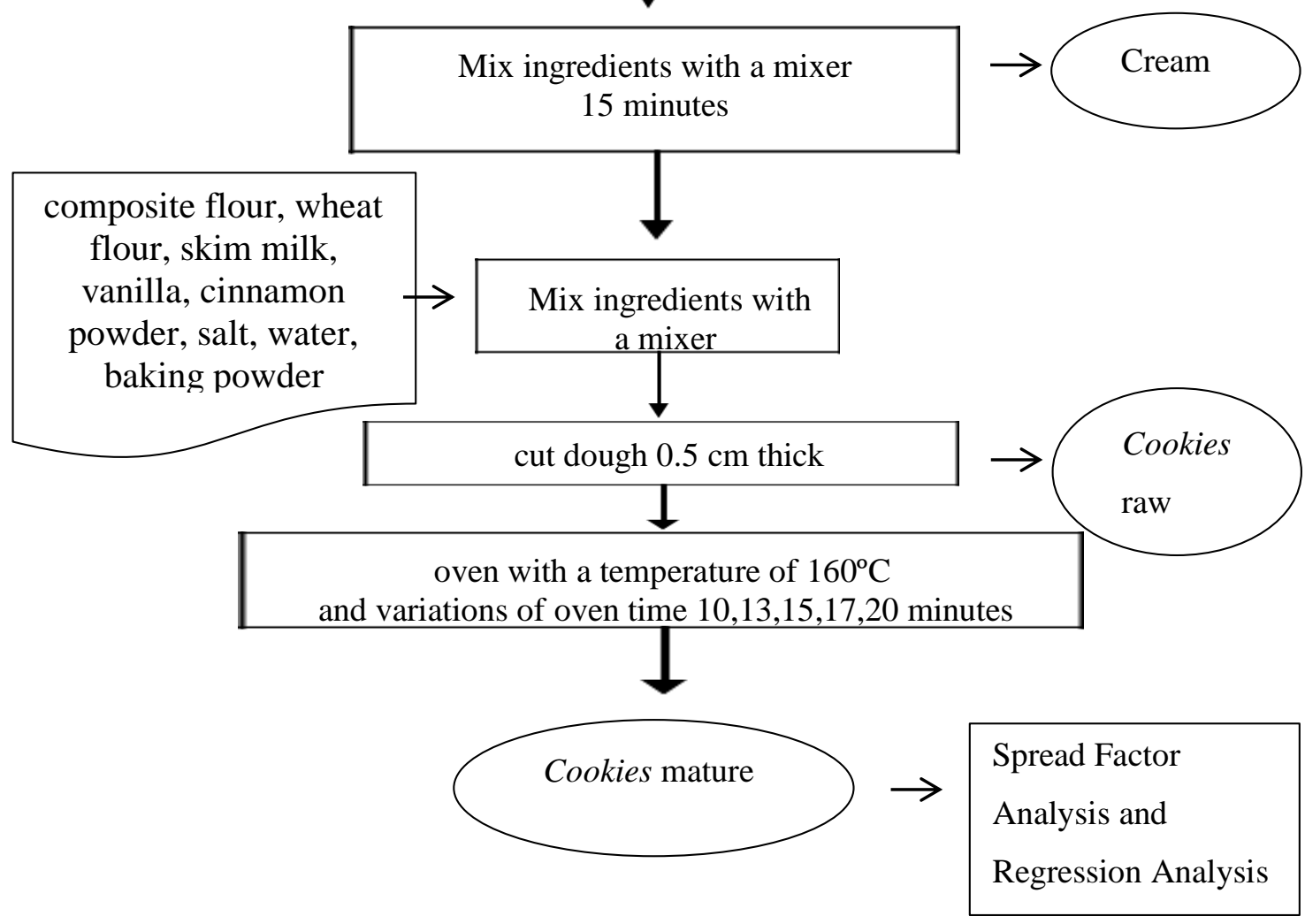

Figure 1 Flowchart of making cookies 


\subsection{Cookies Analysis}

Physical analysis: Cookies were analyzed for width, thickness and dispersion factor following the respective procedure (AOCC, 2002). Width (W): Six cookies are placed horizontally (edge edge) and rotated at an angle of $90^{\circ}$ for reading. Thickness (T): Six cookies placed on each other to calculate the thickness. Spread factor (SF): Calculated according to SF $=$ (W / T x CF) x 10 the following formula: Where; $\mathrm{CF}=$ correction factor (1.0 in this case).

Regression analysis or commonly abbreviated as anareg is a method used to measure the effect of the independent (changing) variable on the dependent variable. (Gujarati, 2006). In this study the fixed variables were temperature, the composition of the composite flour and cake additives, the variable changing was the oven time, the dependent variable was the physical characteristics (spread factor).

Linear regression equation

$\mathrm{Y}=\mathrm{a}+\mathrm{bx} \ldots \ldots \ldots \ldots \ldots \ldots 1)$

Information:

$\mathrm{y}=$ dependent variable

$\mathrm{a}=$ intercept

$\mathrm{b}=$ direction coefficient or beta coefficient.

$\mathrm{x}=$ independent variable

The values of $\mathrm{a}$ and $\mathrm{b}$ can be calculated using the following formula:

$$
\begin{aligned}
& \mathrm{a}=\frac{(\Sigma \mathrm{y})\left(\sum \mathrm{x}^{2}\right)-\left(\sum \mathrm{x}\right)\left(\sum \mathrm{xy}\right)}{\mathrm{n}\left(\Sigma \mathrm{x}^{2}\right)-(\Sigma \mathrm{x})^{2}} \\
& \dot{\mathrm{b}}=\frac{\mathrm{n}(\Sigma \mathrm{xy})-(\Sigma \mathrm{x})(\Sigma \mathrm{y})}{\mathrm{n}\left(\Sigma \mathrm{x}^{2}\right)-(\Sigma \mathrm{x})^{2}}
\end{aligned}
$$

(Gujarati, 2006).

$\mathrm{R}^{2}$ calculation

Coefficient of Determination (R Square)is the ratio of the sum of squares regression (SSR) to the total number of squares (SST). This study calculates R2 using excel output. While the formula is as follows:

(Ghofur, 2019)

$$
\mathrm{R} 2=\frac{\text { the sum of squares regression }(\mathrm{SSR})}{\text { the total number of squares }(\mathrm{SST})}
$$

Chemical / proximate analysis: Cookies were analyzed for moisture, ash, protein, fat, carbohydrate content at the Regional Health Laboratory in Rawasari.

\section{Results And Discussion}

\subsection{Research result}

This research was conducted with a variation of the oven time, namely $10,13,15,17,20$ minutes. Making biscuits is an all-in method, where all the ingredients are mixed together and then stirred to form a dough. The end result of this method will produce a dough that is dense and tends to be hard. After the cold cookies are measured the thickness and width of each oven time using a caliper (accuracy $0.01 \mathrm{~mm}$ ) to determine the best treatment time, then the spread factor obtained is calculated in full as presented in Table 2.

Table 2 The results of the spread factor calculation

\begin{tabular}{|l|l|l|l|}
\hline $\begin{array}{l}\text { Oven Time } \\
\text { (minute) }\end{array}$ & $\begin{array}{l}\text { Width }(\mathrm{W}) \\
(\mathrm{mm})\end{array}$ & $\begin{array}{l}\text { Thickness }(\mathrm{T}) \\
(\mathrm{mm})\end{array}$ & $\begin{array}{l}\text { Spread Factor }(\mathrm{SF}) \\
\mathrm{SF}=(\mathrm{W} / \mathrm{T} \times \mathrm{CF}) \times 10\end{array}$ \\
\hline 10 & 46.13 & 11.75 & 39.25 \\
\hline 13 & 47.26 & 11.87 & 39.81 \\
\hline 15 & 47.67 & 11.94 & 39.92 \\
\hline 17 & 48.53 & 12.11 & 40.07 \\
\hline 20 & 49.26 & 12.18 & 40.44 \\
\hline
\end{tabular}




\subsection{Discussion}

\subsubsection{The Influence of Length of Oven of Time on the Spread Factor}

The physical analysis of cookies is important from both a consumer and a producer perspective. The spread factor for cookies must comply with the specifications set by the manufacturer. There is too much elasticity in the gluten and the dough will resurface to make thicker cookies due to their smaller diameter. Likewise, in terms of too little elasticity, the dough is smaller once it is molded, resulting in thin cookies of large diameter. Based on the graph of the relationship between the time of covenant (x) and the spread factor (y), the value of the equation $\mathrm{y}=0.1116 \mathrm{x}+38.225$ is obtained with a value of $\mathrm{R} 2=0.9604$, this means that with an increase in the time of covenant, the spread factor is greater, and the R2 value shows the correlation of covenant time to the spread factor is interrelated. The analysis shows that the time of the covenant has an influence on the spread of cookies obtained. In this study, the spread factors of cookies obtained at the oven time 10,13,15,17 and 20 minutes were $39,25 \mathrm{~mm} ; 39.81$ $\mathrm{mm} ; 39.92 \mathrm{~mm} ; 40.07 \mathrm{~mm}$; and $40.44 \mathrm{~mm}$; In full, the results of the spread factors of various treatment times are presented in graphical form. as follows.

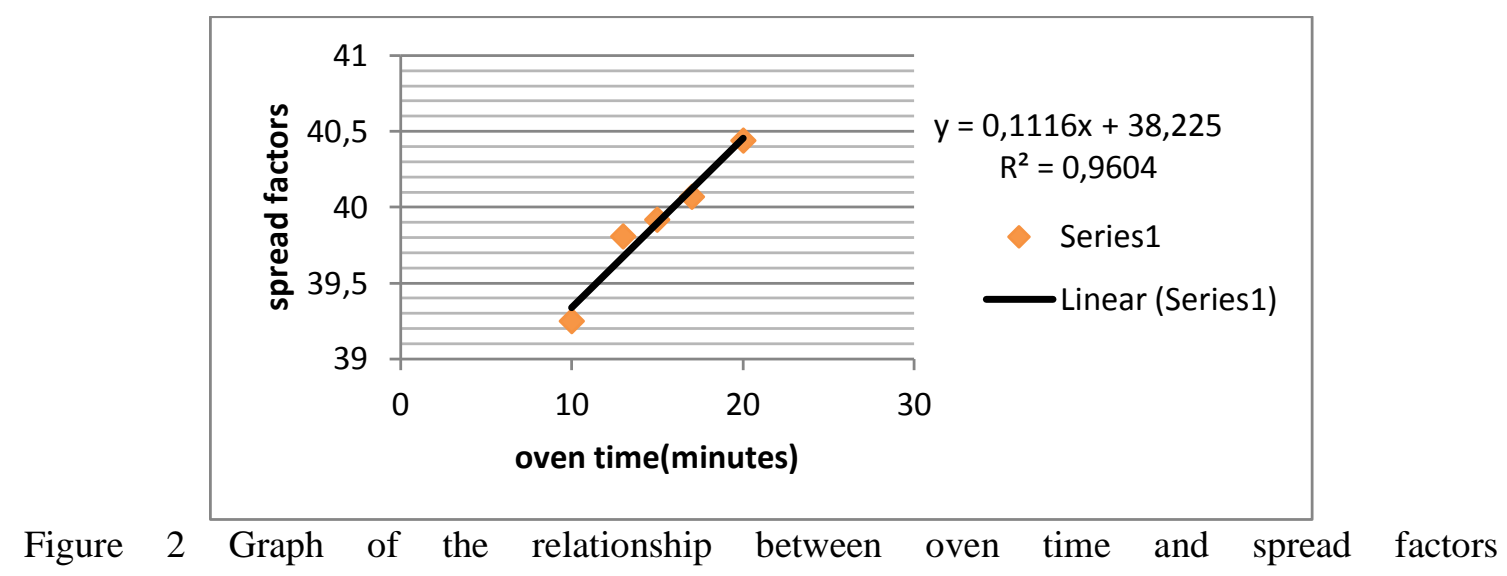




\subsubsection{Proximate Content of Composite Flour Cookies and Cookies Without Composite Flour}

\begin{tabular}{|c|c|c|c|c|c|c|}
\hline \multicolumn{7}{|c|}{ 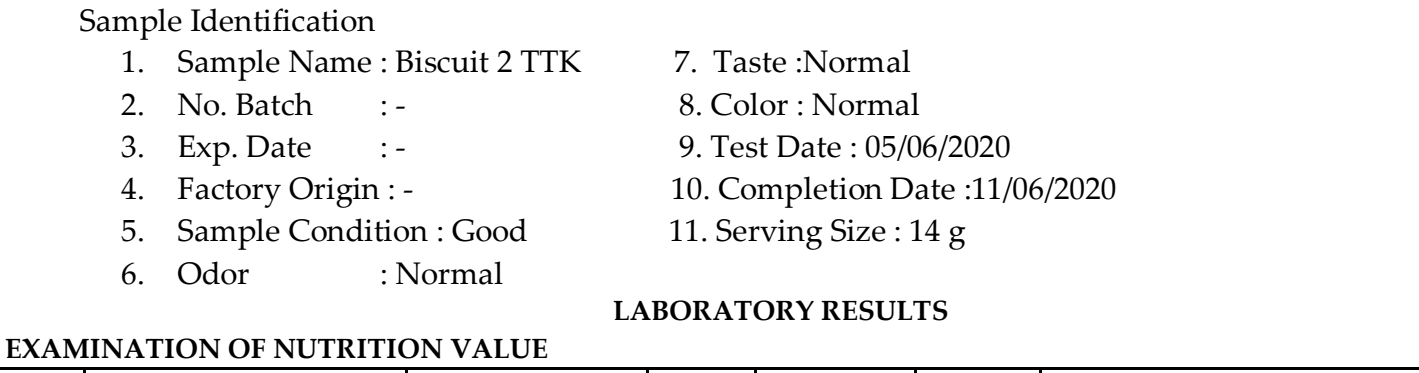 } \\
\hline \multirow{6}{*}{$\begin{array}{c}\text { EXA } \\
\text { No. } \\
1\end{array}$} & \multirow{6}{*}{$\begin{array}{l}\text { ample Identification } \\
\text { 1. Sample Name : } \\
\text { 2. No. Batch : } \\
\text { 3. Exp. Date : } \\
\text { 4. Factory Origin } \\
\text { 5. Sample Conditi } \\
\text { 6. Odor } \\
\text { NATION OF NUTRIT } \\
\text { Parameter } \\
\text { Total Protein } \\
\text { Total Fat } \\
\text { Total Carbohydrates } \\
\text { Water content } \\
\text { Ash content } \\
\end{array}$} & Result & \multirow{6}{*}{$\begin{array}{l}\text { 7. Ta } \\
\text { 8. Co } \\
\text { 9. Te } \\
\text { 10. Co } \\
\text { 11. Se } \\
\text { ORAT } \\
\text { AKG } \\
1 \mathrm{~g} \\
3 \mathrm{~g} \\
9 \mathrm{~g} \\
- \\
-\end{array}$} & \multirow{6}{*}{$\begin{array}{l}\text { e :Norma } \\
\text { r : Norm } \\
\text { Date : 05, } \\
\text { npletion D } \\
\text { ing Size : } \\
\text { RY RESUl } \\
\% \text { RDA } \\
2 \% \\
4 \% \\
3 \% \\
- \\
-\end{array}$} & \multirow{6}{*}{ 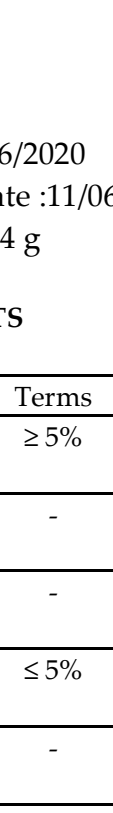 } & \multirow{6}{*}{$\begin{array}{l}\text { } \\
\\
\\
\text { Method } \\
\text { PP.16.20-PROKSI / } 17025 \text { / } \\
\text { LABKESDA } \\
\text { PP.16.20-PROKSI / } 17025 \text { / } \\
\text { LABKESDA } \\
\text { PP.16.20-PROKSI / } 17025 \text { / } \\
\text { LABKESDA } \\
\text { PP.16.20-PROKSI / } 17025 \text { / } \\
\text { LABKESDA } \\
\text { PP.16.20-PROKSI / } 17025 \text { / } \\
\text { LABKESDA } \\
\end{array}$} \\
\hline & & $7.77 \mathrm{~g} / 100 \mathrm{~g}$ & & & & \\
\hline & & $21.58 \mathrm{~g} / 100 \mathrm{~g}$ & & & & \\
\hline & & $61.57 \mathrm{~g} / 100 \mathrm{~g}$ & & & & \\
\hline & & $6.69 \mathrm{~g} / 100 \mathrm{~g}$ & & & & \\
\hline & & $2.39 \mathrm{~g} / 100 \mathrm{~g}$ & & & & \\
\hline
\end{tabular}

Figure 3 Proximate content of cookies without composite flour 


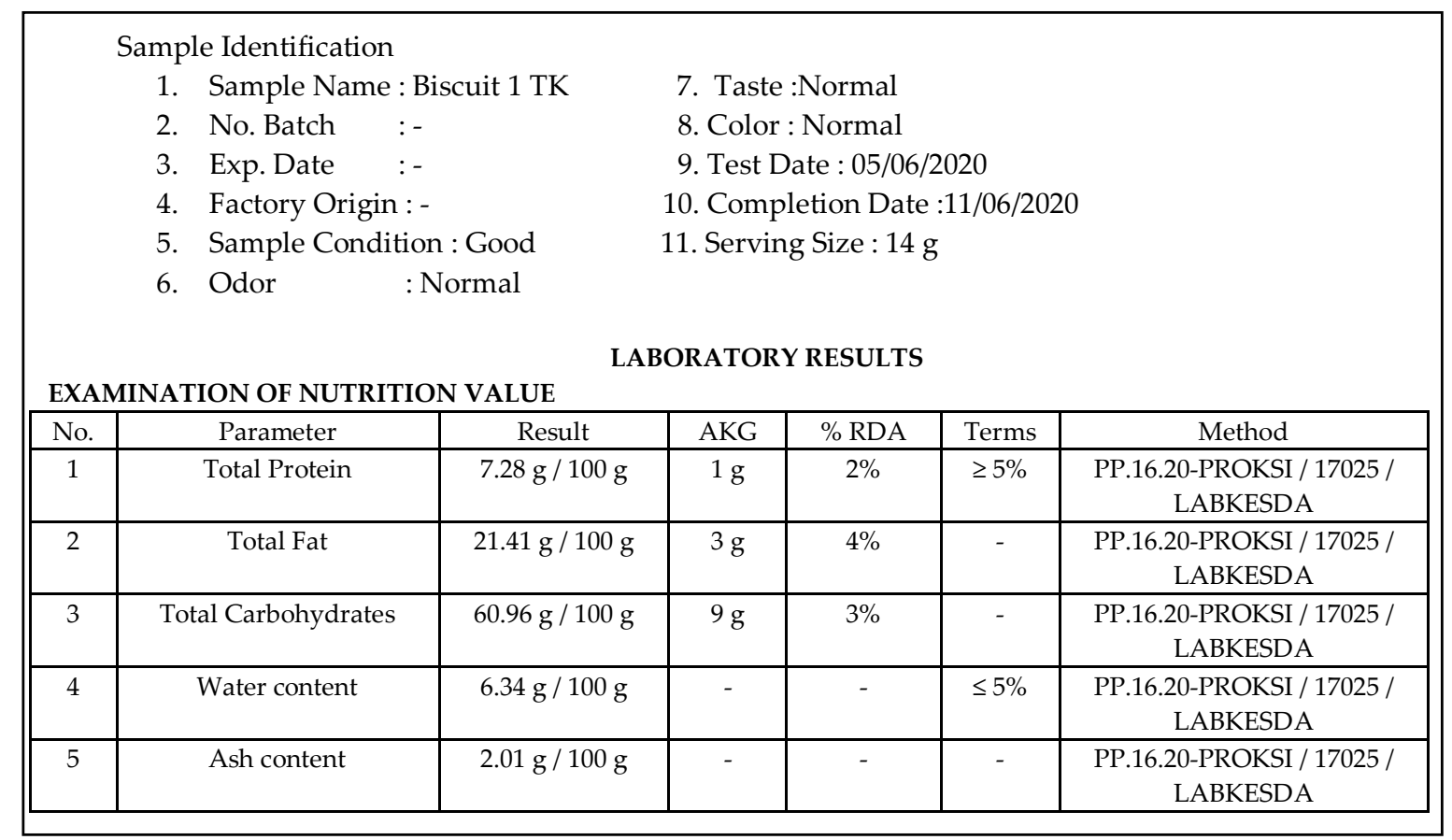

Figure 4. Proximate content of composite flour cookies

Figures 3 and 4 are the results of the proximate content of cookies without composite flour and composite flour cookies. Cookies without composite flour are comparison / control cookies. In this study, the moisture content in the composite flour cookies and control cookies has increased and exceeds the national quality standard for the moisture content of cookies (maximum 5\%) because the delivery to the Central Jakarta Regional Health Laboratory takes several days and the packaging is not too airtight. The difference in results occurred in the ash content of protein, fat, and carbohydrate, in this study the ash, protein, fat and carbohydrate content were in accordance with the national quality standards for cookies but the ash, protein, fat and carbohydrate content of composite flour cookies decreased along with the increase in the percentage of flour. composites, Decreased content of ash, protein, fat,

In the 2018 Kusumawardhani research, the increase in biscuit ash content along with the increasing percentage of use of composite flour showed an increase in the mineral content of biscuits with composite flour. The composite flour used contributes to the mineral content of the biscuits. Similar results were found in other studies using banana flour as one of the constituents of composite flour, showing an increase in ash content along with the increasing number of composite flour. The same thing happened to the fat content of the biscuits. The difference in results occurred in the protein content, in this study the protein content decreased along with the increase in the percentage of composite flour.

\section{Conclusions}

\subsection{Conclusion}

From the research carried out, the following conclusions can be drawn:

1. On the effect of oven time (x) 10,13,15,17, and 20 minutes affect the value spread factor (y),namely the spread factor calculated using the relationship between the spread ratio, width, and thickness and the correlation on cookies. The highest score is thereat 20 minutes, which is 40.44 $\mathrm{mm}$ with the equation value $\mathrm{y}=0.1116 \mathrm{x}+38.225$ with a value of $\mathrm{R} 2=0.9604$. Measurement of the width and thickness of cookies using a caliper accuracy $0.01 \mathrm{~mm}$.

2. Proximate level cookies Composite flour includes protein $7.77 \mathrm{~g} / 100 \mathrm{~g}$, fat $21.58 \mathrm{~g} / 100 \mathrm{~g}$, carbohydrates $61.57 \mathrm{~g} / 100 \mathrm{~g}$, moisture content $6.69 \mathrm{~g} / 100 \mathrm{~g}$, ash content $2.39 \mathrm{~g} / 100 \mathrm{~g}$. While the proximate content of biscuit cookies without composite flour include protein $7.28 \mathrm{~g} / 100 \mathrm{~g}$, fat 
$21.41 \mathrm{~g} / 100 \mathrm{~g}$, carbohydrates $60.96 \mathrm{~g} / 100 \mathrm{~g}$, moisture content $6.34 \mathrm{~g} / 100 \mathrm{~g}$, ash content $2,01 \mathrm{~g}$ $/ 100 \mathrm{~g}$.

3. The spread factor is greatly influenced by the oven time. The best spread factor of 40.44 resulted in a more nutritious and healthier product at 20 minutes of oven time.

\subsection{Suggestion}

1. This research can be developed by examining other variables such as the composition of the composite flour and ingredients the standard used.

2. It is hoped that the next research can use other methods such as making cookies with the creaming method.

3. It is necessary to pack with a more airtight material so that it can increase proximate content of cookies.

\section{Acknowledgement}

The authors would like to express gratitude to the Ministry of Research and Technology Republic of Indonesia/ BRIN, LLDIKTI III, LPPM UMJ, and Department of Chemical Engineering, Faculty of Engineering at Universitas Muhammadiyah Jakarta for the facility and financial supports throughout this research.

\section{References}

[1] AOAC. 2002. Official methods of analysis. Associated of Analytical Chemists. Washington. DC. USA.

[2] Arifin, Bustanul. 2005. Indonesian Agricultural Economic Analysis. Jakarta: Kompas Book Publisher.

[3] Central Statistics Agency. 2018. Wheat Flour Commodities in Indonesia. National Standardization Agency for Indonesia, Jakarta.

[4] National Standardization Body. 1992. Indonesian National Standard. Cookie Quality Requirements (cookies). SNI 01-2973-1992. National Standardization Agency for Indonesia, Jakarta.

[5] Ghofur, M. Abdul. 2019. Coefficient of Determination in Regression Analysis. E-learning

[6] Gujarati, Damodar N. 2006. Basic Econometrics. Jakarta: Erlangga Publisher.

[7] Kusumawardani, Hastin Dyah, et al. 2018. Nutritional content, organoleptics, and shelf life of biscuits with composite flour substitution (Moringa leaves, seaweed, and banana) Magelang Health Research and Development Center, Kapling Jayan Borobudur, Magelang, Indonesia

[8] Matz SA, Matz TD. 1978.Cookies and Crackers Technology. Connecticut: The AVI Publishing Company. 